\title{
Ceramic Tile Adhesives from the Producer's Perspective: A Literature Review
}

\author{
Jacek Michalak $\mathbb{1}$
}

Citation: Michalak, J. Ceramic Tile Adhesives from the Producer's Perspective: A Literature Review. Ceramics 2021, 4, 378-390. https:// doi.org/10.3390/ceramics4030027

Academic Editors: Enrico Bernardo and Gilbert Fantozzi

Received: 14 May 2021

Accepted: 16 June 2021

Published: 27 June 2021

Publisher's Note: MDPI stays neutral with regard to jurisdictional claims in published maps and institutional affiliations.

Copyright: (C) 2021 by the author. Licensee MDPI, Basel, Switzerland. This article is an open access article distributed under the terms and conditions of the Creative Commons Attribution (CC BY) license (https:// creativecommons.org/licenses/by/ $4.0 /)$.
Research and Development Center, Atlas sp. z o.o., 2, Kilinskiego St., 91-421 Lodz, Poland; jmichalak@atlas.com.pl

\begin{abstract}
Ceramic tiles and ceramic tile adhesives (CTA) are two impressive materials that have changed construction history. Ceramic tiles could not provide their beauty and durability for buildings when used as a covering both for the inside and exterior finishing without CTA. Nowadays, they are complex multi-component systems. Among the various CTAs, cementitious products are the most commonly used. This article presents an extensive review of the literature, showing how they are perceived in the scientific literature today. In this paper, an attempt is made to review individual adhesives' ingredients' effects on their properties, with particular reference to redispersible polymer powders and methylcellulose ethers. The article presents the basics of the CTAs, assessing and verifying the constancy of their performance in force in European Union countries. Furthermore, it gives a critical review of CTA's normalized measurement methodologies. The study also draws attention to the need to consider measurement uncertainty in decision-making and conformity assessment, supported by an analysis of the results of multi-annual inter-laboratory studies and market surveillance tests. Future research suggestions are also made based on the review, mainly from the adhesive manufacturer's perspective.
\end{abstract}

Keywords: ceramic tile adhesive; ceramics; construction products

\section{Introduction}

Ceramic tiles have been used for centuries as decorative elements inside and outside of buildings of all kinds, including residential homes, public buildings and places of worship. Their history goes back to antiquity: Egypt, Assyria and Babylonia (e.g., the Ishtar Gate, one of the most beautiful and impressive examples of glazed bricks). The Romans and Greeks also used decorative tiles. Their growing use was connected with the Islamic expansion. Finally, in the Middle Ages, they became popular in Europe. The industrial revolution made tiles widely available. Ceramic tiles have been valued for centuries due to their durability and exceptional resistance to external factors. The relative maintainability of their cleanliness is also essential [1]. Nowadays, ceramic tiles in many traditional applications have to compete with glass, metal, high-pressed laminates and other covering materials. This is especially true when building architecture requires features that go beyond beauty and durability. This is also because construction has already moved and is still moving forward to the era where productivity is the keyword.

It would be impossible to use ceramic tiles without the material to stick them to the substrate, i.e., the adhesive connecting these materials. For thousands of years, construction was associated with the use of mineral binders like gypsum, lime, pozzolans (volcanic ash), or cement [2]. It is precisely the mortars using the mineral binders that were also used for the installation of ceramic cladding.

In 2019, 12.673 billion square meters of ceramic tiles were produced worldwide (a decrease of 3.7\% compared to the previous year, 2018), while the consumption of ceramic cladding was 12.375 billion $\mathrm{m}^{2}$ (a decrease of $4.1 \%$ compared to 2018) [3]. Assuming an average consumption of $4 \mathrm{~kg} / \mathrm{m}^{2}$, this means the use of slightly less than 50 million tons of the commonly used cementitious adhesives for tiles. One of the global marketing research 
agencies, in 2020, estimated that the dry-mix mortar (renders and plasters, ceramic tiles adhesives, masonry mortars, joint and crack fillers, screeds, and flooring compounds) market size was over 260 million tons [4]. According to this study, ceramic tile adhesives (CTAs) had a share of slightly more than $25 \%$ in all types of dry-mix mortars, which means a little less than 70 million tons of manufactured products. The difference in these data is due to several reasons, including the different definitions/understanding of the term CTA, the different standards of works related to laying ceramic tiles, the different technologies and materials used, and the difficulty of obtaining reliable sales data. The latter is visible, for example, when comparing the data of two CTA market size surveys. According to one of them, the global CTA market was projected to be USD 8.23 billion in 2019, and to reach USD 13.98 billion by 2029 at a compound annual growth rate (CAGR) of 5.5\%. [5]. According to another study, the global CTA market was valued at USD 15.08 billion in 2018, and is projected to reach USD 40.73 billion by 2026, growing at a CAGR of 13.3 from 2019 to 2026 [6]. Regardless of the difficulties in precisely defining the size of the CTA market, it is undeniable that it is an important group of building materials that are constantly developing $[2,7,8]$.

As a result of the development of science, the development of the building material industry, the development of construction technologies, and the growing market expectations in the 1960s, the production of factory-mixed dry mortars started to grow [2]. Initially, the development of dry-mix mortar technology was related primarily to Germany and other Western European countries, and the USA. The primary factors that influenced the development of dry-mix mortar technology include the limited resources of skilled workers, the need to shorten construction operation times, and increasing labor costs. Furthermore, the growing number of specialized applications, the related need to use appropriate construction products, and users' rising expectations played an influential role. Factory-made dry mix mortars eliminated the possibility of errors that could occur when using job-site-mixed mortars. The development of dry-mix mortar technology in Germany in the years 1960-1995 allowed for a sixfold increase in the amount of render and plaster mortars used, while reducing employment by $25 \%$ [2]. The Polish system transformation of 1989 initiated a successful development of dry-mix mortar technology in Central and Eastern Europe [9]. The following years brought enormously growth to other new markets, including Russia and the Middle-East [8]. Today, dry-mix mortar technology is widely used. There are no precise data on the number of functioning dry-mix mortar plants. In 2007, in Europe, there existed about 790 plaster and mortar works, in which about 41.5 million tons of premixed dry mortars were produced [7]. However, there is no doubt that there are thousands of dry-mix mortar plants in the world in which mineral and polymer binders are mixed with fillers/aggregates and chemical additives, modifying the properties of mortars in a well-defined way (mixing method and time, automatic computer-controlled processes). Then, dry-mix mortars are packed in bags or silos and delivered to the sales places or construction sites. After adding a strictly defined amount of water at the construction site to the dry-mix mortar, they are applied.

\section{Composition of Ceramic Tile Adhesives}

Cementitious CTAs are the most commonly used type of thin-bed mortars for tiling ceramic tiles. The use of dispersion adhesives and adhesives based on reactive resins is significantly lower, and they are not discussed in this paper. Due to this reason, only the cementitious adhesives for ceramic tiles are the subject of consideration of this article.

Ceramic tiles can be installed inside (bathrooms, kitchens, offices and other rooms) and outside buildings (terraces, balconies and building facades). Today, a wide variety of ceramic tiles are offered, glued to various substrates, both on horizontal and vertical surfaces. The composition of the CTA should be designed so that the properties of the adhesive give the desired effect and meet the expectations of all of the participants in the construction process, i.e., the investor, contractor and construction inspector. 
The CTAs used today are complex multi-component systems. Thin-bed ceramic tile adhesives are composed of binder/binders, aggregates and chemical additives. In most cases, meeting the requirements of modern users necessitates the use of two binders to produce CTAs, i.e., mineral, Portland types of cement, sometimes with the addition of high-alumina cement, and polymer, in the form of redispersible polymer powder (RPP). Aggregates serve as a reinforcing and structural element, increasing the strength of the CTA. Generally, aggregates ensure the packing density, flexural strength and durability. The most commonly used aggregates are quartz fillers with quartz sand granulation in the range of $0.05-0.50 \mathrm{~mm}$. Apart from quartz, limestone, light and special fillers are also used. Among the chemical additives usually used up to $1 \%$ are water-retention agents/thickeners (mainly chemically modified cellulose derivatives), and sometimes modified starch derivatives and cellulose fibers, accelerators, retarders, and deformers play a unique role in CTA. In the following, we will discuss the influence of the components mentioned above on cementitious CTA properties.

\subsection{The Specificity of Thin-Layer Mortars}

In the case of construction mortars containing Portland cement, the reaction of the clinker components with water leads to the setting and hardening of the mortar. Water is needed in the mortar over a prolonged period for the cement setting processes to take place. In the case of thick-layer mortars, i.e., systems with a low surface area to volume ratio, the amount of water is usually sufficient for the setting processes. In thin-layer mortars, where the surface-to-volume ratio is much higher than in the case of thick-layer systems, there is typically a deficit of water, which evaporates on the surface or is pulled through the substrate by capillary forces. This leads to a reduction in the hydration processes (sometimes the hydration degree is below 30\%), the rapid hardening of the mortar, and the deterioration of the properties of the hardened mortar, which can significantly affect the durability and service life of the mortar [10]. This is a common problem of the thin-layer mortar system. This problem was well demonstrated by Schulze et al., who compared the compressive and flexural strength for a mortar using two different specimens: the standard prism of $40 \times 40 \times 160 \mathrm{~mm}$ dimensions and a $10 \times 40 \times 160 \mathrm{~mm}$ prism [11]. The study compared the flexural and compressive strength for the cementitious mortar stored for 28 days in dry-air conditions $\left(23^{\circ} \mathrm{C} / 50 \%\right.$ r.h.) and after immersion in water for both measurement prisms. The samples' compressive strength and flexural strength after storage in water were higher for both measurement prisms than those for the pieces stored in dry-air conditions. In the case of the prism with dimensions of $10 \times 40 \times 160 \mathrm{~mm}$, for which the surface-to-volume ratio was four times higher than in the case of the standard prism $(40 \times 40 \times 160 \mathrm{~mm})$, immersion in water led to a much higher increase in the compressive and flexural strength (the effect of a much higher degree of hydration caused by the greater water availability).

\subsection{Influence of Cellulose Derivatives (CDs) on the Properties of CTAs}

Among the ingredients modifying the properties of CTAs, so that they meet the requirements facing them today, a special place is occupied by chemically modified cellulose derivatives (CDs). The properties of CDs or other water-retention agents should always match the specific purpose of the construction mortar. Among the various CDs, the following are mostly used in CTA applications: methyl hydroxyethyl cellulose (MHEC), methyl hydroxypropyl cellulose (MHPC) and hydroxyethyl cellulose (HEC). Their addition to any construction mortar, including CTA, causes the retardation of the cement hydration. It creates changes in the microstructure of the adhesive. It increases plasticity, affects the viscosity and workability, and ensures higher water retention in the mortar. The presence of CD influences the properties of both fresh and hardened adhesive [2,12].

Although CDs in the form of cellulose ethers have been used since the beginning of the 1960s for mortar modification [13], and the construction sector held the largest market share among all CD applications [14], not many papers have been published on the 
mechanisms by which CDs affect cement hydration [15-22]. This is due to the complexity of the cement hydration process, during which the reactions of different clinker phases with water overlap. The poly-mineral composition of cement grains additionally complicates the whole process. From the CTA formulator's point of view, research concerned with CDs' influence on various selected properties of building mortars is more important [13,23-26].

Cellulose ethers allow the increase of the adhesion of fresh mortar to the substrate, which also positively affects the adhesion of the mortar after it has hardened. CDs (MHEC and MHPC) also stabilize the air pores in the mortar [24,27]. CDs stabilize the air bubbles introduced into the mortar during mixing, which in most cases is a desired phenomenon and affects the application parameters of the mortar, including its workability. On the other hand, too much air affects the mechanical properties: adhesion, compressive and flexural strength depend on the density exponentially. Moreover, the ability to stabilize the introduced air affects the efficiency of the mortar's application, which depends on the maximum water-to-binder ratio and the total air volume. The most desirable effect of using cellulose ethers in building mortars is their strong affinity for water and its retention $[25,28]$. The water stored by the cellulose ether provides the appropriate conditions for the setting and hardening of the cementitious binders. Cellulose ether, due to the specific function of the water storage, has a positive effect on the strength parameters of the mortars, including their adhesion to the substrate [10].

Cellulose ethers are often not the only rheology modifiers/thickeners in formulations of the CTA. Today, they are commonly mixed in the CTA with other water-retention agents, such as starch ethers, polyacrylamide, or inorganic (bentonite, sepiolite) modifiers [29].

\subsection{Influence of Redispersible Polymer Powders on the Properties of CTAs}

The CTAs used today would not meet the expectations of users and the requirements resulting from the regulations on the placement of a construction product on the market without the modification of their properties through the use of redispersible polymer powders (RPPs). Polymers have been used to modify mortars since ancient times. Egyptians and Romans modified lime plasters using natural polymers, such as Arabic gum, glutin glues produced from animal skins or bones, and fig juice. They and others also used egg yolks, casein, milk protein, proteins from horns, and the claws of wild and farm animals to modify building mortars [30]. Before the "era" of RPPs in the 1950s and 1960s, polymers were widely used as water dispersion to improve cementitious mortars. The use of two-component systems - cementitious dry-mix and dispersion-was associated with the possibility of using the incorrect proportions as a result of human error on the construction site. In addition, the liquid component in the system was sensitive to the action of microorganisms. These inconveniences were eliminated by the fact that, in the 1950s, RPP was obtained (RPP is an organic polymer material obtained in the spray-drying process from dispersion); the fact that, in 1970, RPP was a copolymer containing ethylene in its composition was an important factor in the development of CTAs with increased parameters (class C2) [2,12]. RPPs, similarly to cellulose ethers, affect both the properties of fresh and set mortars [31-36]. An undesirable side effect of polymeric additives (both RPPs and cellulose ethers) in the CTA formulation is the formation of a dry skin on the mortar surface $[33,37]$. This is created due to water drying from the surface layer. The dry external layer (skin) has different properties to the bulk body underneath. The thickness of the skin (the external surface layer) ranges from $0.1 \mathrm{~mm}$ (initial) to $1 \mathrm{~mm}$ about $30 \mathrm{~min}$ after applying fresh CTA [37]. The skin's formation on the CTA's surface limits its application, mainly when the skin is formed before the ceramic tile is applied [38].

For CTAs, adhesion to the substrate is the most desirable feature. The presence of RPP in the CTA significantly increases the value of this parameter [31-33,39-42]. RPPs increase the tensile strength of cementitious mortars. This is crucial in the case of thin-layer mortars [31,32,42]. The increase in tensile strength is related to the positive effect on the ability to bridge cracks, and to the transverse deformation (also known as elasticity) of polymer-modified mortar [43]. The vast majority of studies on the influence of RPPs 
on the compressive strength in cement systems showed that the value of this property is reduced [31-34,44]. Independent research by Sakai et al. [31] and Schultze et al. [45] showed that the decrease in compressive strength is directly proportional to the polymer additive's concentration. Additionally, both researchers showed that the amount of powder used does not affect the durability of the mortar. All of the tests proved the increase in the flexural strength of cement systems modified by RPPs [31,32,34,44,46,47]. In addition, it was observed that the increase in flexural strength is significantly influenced by the maturation conditions of the mortar samples for testing [47]. The studies by Sakai et al. showed that the maximum increase in flexural strength was observed after adding $10 \%$ by weight RPP to the cement, and a further increase in the amount of RPP in the system did not cause any changes. Another important aspect of RPP-modified cement systems is their durability. Durability is an important aspect when considering the system of mixed binders based on mineral-polymer binders and their environmental performance. Research by Mirza et al. showed that the modification of cement mortars with polymers increases the resistance of the mortar to freeze-thaw cycles [48]. Studies made by Schulze and Killermann of polymer-modified mortars subjected to outdoor and indoor exposure, using scanning electron microscopy, showed no changes in the morphology of the polymers in the mortars over the ten years of exploitation [45].

Other properties that are the subject of research on polymer-modified mortars include, among other things, the aeration of the mixture [35], the ability to reduce the amount of water to needed to prepare fresh mortar [44], and the increase of the water retention capacity of the system [34]. Of course, in mortars, the water retention capacity is mainly due to the use of cellulose ethers [49]. Wang et al. showed that RPPs have such properties; the concentrations for which similar effects are observed for cellulose ethers are at least one order of magnitude higher [34].

RPPs are characterized by the ability to inhibit cement hydration processes [34,50,51]. Despite the many years of research carried out in many centers around the world, it is not possible to indicate whether the interactions between the clinker phases undergoing hydration, the products of hydration of the clinker phases and the produced cement matrix, and the polymer contained in the system are only physical, or whether the observed modification effects are the result of synergistic coexisting physical and chemical interactions [52-56]. Various conclusions are drawn about the nature of the cement-polymer interaction $[33,35,36,57-60]$.

\section{Formulation of the CTAs}

Modern CTAs contain a dozen components. Such an amount of ingredients in an appropriate composition is necessary to meet the requirements of modern CTAs given by their users. Many sample CTA recipes are available, but the producers' compositions are their key intellectual property.

Cementitious CTAs are produced in plants that typically supply customers with their products within a radius of $120-200 \mathrm{~km}$. Manufacturers try not to deliver their products over $200 \mathrm{~km}$ because CTAs are relatively cheap construction materials (especially C1 class CTAs), and the influence of the transport costs of the final product and raw materials is noticeable. Manufacturers of CTAs, when formulating the recipes of their products, must take into account many aspects, among which the following should be considered:

- compliance with the minimum classification requirements specified in the relevant standards, including:

(a) the variability of the raw materials of local origin (cement, aggregates, other inert ingredients);

(b) in the case of producers offering the product from different production locations, the need to optimize (average) the product quality;

(c) the variability resulting from the measurement uncertainty of the test methods used;

- the real conditions of use on the construction site; 
- fulfilling the expectations of tile fixers (appreciation) in terms of product friendliness in the broad sense, i.e., the ease of application, fresh-state application properties, and parameters not specified in the standards constituting the basis for the assessment of the product resulting from legal provisions;

- the competitiveness against other products intended for similar uses, including:

(a) technical dimensions;

(b) manufacturing costs;

- the competitiveness of the CTAs against other products: defining the ability of CTAs to compete with substitutional goods towards downstream clients.

\section{Testing of the CTAs}

\subsection{Assessment and Verification of the Constancy of the Performance of the CTAs}

In 2001, as a result of CEN/TC 67/WG 3 activity, the European Standard EN 12004:2001 [61] was established, which specified the requirements for CTAs. So far, the standard has been amended several times: EN 12004:2001/ A1:2002/AC:2002, EN 12004:2007, EN 12004:2007+A1:2012 and EN 12004-1:2017. The latest version of the standard with the requirements for CTAs published in the list of European harmonized standards [62] is EN 12004:2007+A1:2012 [63]. The next version of the standard published by CEN in 2017, EN 12004-1:2017 [64], has not yet been included in the list of harmonized standards published in the Official Journal of the European Union, and therefore cannot be the basis for the assessment and verification of the constancy of performance. Although the CPR rules have been in force for seven years [65], the document used in the process of assessing and verifying the constancy of the performance of tile adhesives is a standard from the old legal order, i.e., from the time of Directive 89/106/EEC Construction products [66]. Before 2001, various national standards operated in EU countries. The lack of requirements which were applicable to all of the participants of the construction market in the EU countries made it difficult and often impossible to evaluate the product objectively compared to other competing products, not to mention the free movement of goods between the Member States [67].

The EN 12004 standard, apart from cementitious adhesives, also applies to dispersion adhesives and adhesives based on reactive resins for ceramic tiles. The EN 12004 standard divided cement adhesives for ceramic tiles into two main classes (groups): those with basic properties, marked as $\mathrm{C} 1$, and those with enhanced parameters, marked as $\mathrm{C} 2$. Table 1 shows the requirements for cementitious CTAs under EN 12004: 2007+A1:2012.

Table 1. Requirements for cementitious (C) adhesives for ceramic tiles (CTA) according to EN 12004:2007+A1:2012 [63].

\begin{tabular}{lcc}
\hline Fundamental Characteristics & & \\
\hline Characteristics & Requirement & Test Method \\
\hline Normal setting adhesives (C1) & & \\
\hline Initial tensile adhesion strength & $\geq 0.5 \mathrm{~N} / \mathrm{mm}^{2}$ & 8.2 of EN 1348 \\
Tensile adhesion strength after water immersion & $\geq 0.5 \mathrm{~N} / \mathrm{mm}^{2}$ & 8.3 of EN 1348 \\
Tensile adhesion strength after heat aging & $\geq 0.5 \mathrm{~N} / \mathrm{mm}^{2}$ & 8.4 of EN 1348 \\
Tensile adhesion strength after freeze-thaw cycles & $\geq 0.5 \mathrm{~N} / \mathrm{mm}^{2}$ & 8.5 of EN 1348 \\
Open time: tensile adhesion strength & $\geq 0.5 \mathrm{~N} / \mathrm{mm}^{2}$ & EN 1346 \\
\hline Fast setting adhesives (C1F) & & \\
\hline Early tensile adhesion strength & $\geq 0.5 \mathrm{~N} / \mathrm{mm}^{2}$ & 8.2 of EN 1348 \\
Open time: tensile adhesion strength & $\geq 0.5 \mathrm{~N} / \mathrm{mm}^{2}$ & EN 1346 \\
All other requirements as in Table 1a of EN 1348 & & EN 1348 \\
\hline
\end{tabular}


Table 1. Cont.

\begin{tabular}{|c|c|c|}
\hline \multicolumn{3}{|l|}{ Optional Characteristics } \\
\hline \multicolumn{3}{|l|}{ Special Characteristics } \\
\hline Slip & $\leq 0.5 \mathrm{~mm}$ & EN 1308 \\
\hline Extended open time: tensile adhesion strength & $\geq 0.5 \mathrm{~N} / \mathrm{mm}^{2}$ & EN 1346 \\
\hline Deformable adhesive: transverse deformation & $\geq 2 . \overline{\mathrm{mm}}$ and $<5 \mathrm{~mm}$ & EN 12002 \\
\hline Highly deformable adhesive: transverse deformation & $\geq 5 \mathrm{~mm}$ & EN 12002 \\
\hline \multicolumn{3}{|l|}{ Additional characteristics (C2) } \\
\hline High initial tensile adhesion strength & $\geq 1 \mathrm{~N} / \mathrm{mm}^{2}$ & 8.2 of EN 1348 \\
\hline High initial adhesion strength after water immersion & $\geq 1 \mathrm{~N} / \mathrm{mm}^{2}$ & 8.3 of EN 1348 \\
\hline High tensile adhesion strength after heat aging & $\geq 1 \mathrm{~N} / \mathrm{mm}^{2}$ & 8.4 of EN 1348 \\
\hline High tensile adhesion strength after freeze-thaw cycles & $\geq 1 \mathrm{~N} / \mathrm{mm}^{2}$ & 8.5 of EN 1348 \\
\hline \multicolumn{3}{|l|}{ Fundamental Characteristics } \\
\hline Characteristics & Requirement & Test Method \\
\hline \multicolumn{3}{|l|}{ Normal setting adhesives (C1) } \\
\hline Initial tensile adhesion strength & $\geq 0.5 \mathrm{~N} / \mathrm{mm}^{2}$ & 8.2 of EN 1348 \\
\hline Tensile adhesion strength after water immersion & $\geq 0.5 \mathrm{~N} / \mathrm{mm}^{2}$ & 8.3 of EN 1348 \\
\hline Tensile adhesion strength after heat aging & $\geq 0.5 \mathrm{~N} / \mathrm{mm}^{2}$ & 8.4 of EN 1348 \\
\hline Tensile adhesion strength after freeze-thaw cycles & $\geq 0.5 \mathrm{~N} / \mathrm{mm}^{2}$ & 8.5 of EN 1348 \\
\hline Open time: tensile adhesion strength & $\geq 0.5 \mathrm{~N} / \mathrm{mm}^{2}$ & EN 1346 \\
\hline \multicolumn{3}{|l|}{ Fast setting adhesives (C1F) } \\
\hline Early tensile adhesion strength & $\geq 0.5 \mathrm{~N} / \mathrm{mm}^{2}$ & 8.2 of EN 1348 \\
\hline Open time: tensile adhesion strength & $\geq 0.5 \mathrm{~N} / \mathrm{mm}^{2}$ & EN 1346 \\
\hline All other requirements as in Table 1a EN 1348 & & EN 1348 \\
\hline \multicolumn{3}{|l|}{ Optional Characteristics } \\
\hline \multicolumn{3}{|l|}{ Special Characteristics } \\
\hline Slip & $\leq 0.5 \mathrm{~mm}$ & EN 1308 \\
\hline Extended open time: tensile adhesion strength & $\geq 0.5 \mathrm{~N} / \mathrm{mm}^{2}$ & EN 1346 \\
\hline Deformable adhesive: transverse deformation & $\geq 2 . \overline{\mathrm{mm}}$ and $<5 \mathrm{~mm}$ & EN 12002 \\
\hline Highly deformable adhesive: transverse deformation & $\geq 5 \mathrm{~mm}$ & EN 12002 \\
\hline \multicolumn{3}{|l|}{ Additional characteristics (C2) } \\
\hline High initial tensile adhesion strength & $\geq 1 \mathrm{~N} / \mathrm{mm}^{2}$ & 8.2 of EN 1348 \\
\hline High initial adhesion strength after water immersion & $\geq 1 \mathrm{~N} / \mathrm{mm}^{2}$ & 8.3 of EN 1348 \\
\hline High tensile adhesion strength after heat aging & $\geq 1 \mathrm{~N} / \mathrm{mm}^{2}$ & 8.4 of EN 1348 \\
\hline High tensile adhesion strength after freeze-thaw cycles & $\geq 1 \mathrm{~N} / \mathrm{mm}^{2}$ & 8.5 of EN 1348 \\
\hline
\end{tabular}

In terms of the deformability of cementitious CTAs, there are two types of products according to the EN 12004: deformable adhesives (S1) with transverse deformation $\geq 2.5 \mathrm{~mm}$ and $\leq 5.0 \mathrm{~mm}$, and highly deformable adhesives (S2) with transverse deformation $\geq 5.0 \mathrm{~mm}$.

The authors of the EN 12004 standard (CEN/TC 67/WG 3) adopted as the essential characteristics of cementitious CTAs the adhesion and open time, i.e., the maximum time after applying the CTA when the tiles can be embedded into the adhesive layer to obtain the required adhesion. The adhesion measurement is performed after the mortar has been stored in various laboratory conditions, simulating the real conditions in which cementitious CTAs are used. In the initial stage of the development of EN 12004, the authors also considered shear strength as one of the characteristics of cementitious CTAs. Due to the slight differences in the measured offset (in tenths of a millimeter), the authors rejected the possibility of using the shear strength to characterize cementitious CTAs.

EN 12004:2007 + A1:2012 is a standard established by the Comité Européen de Normalization (CEN), and it is valid in the EU and European Free Trade Association (EFTA) 
countries. Taking into account that, in 2019 , the consumption of ceramic tiles in 28 countries belonging to the EU amounted to 920 million square meters [3], and that the EFTA includes only four countries (Iceland, Liechtenstein, Norway, and Sweden), the coverage of EN 12004 is slightly over $7.4 \%$. However, it is worth noting that the requirements for AVCP for cementitious adhesives in force in EU countries since 2001 were implemented in 2004 by the International Organization for Standardization (ISO), which established the ISO 13007 series of standards [68]. Thus, the requirements for cementitious CTAs are standardized in most countries of the world.

\subsection{Critical Remarks on the Laboratory Test Methods According to EN 12004}

As mentioned before, the key to the classification of cementitious CTAs is their adhesion determined by the tensile strength. In this aspect, it is worth looking into the measurement methodology. From a practical point of view, perhaps the most interesting point for the manufacturers of CTAs is the reproducibility of the results, i.e., the degree of agreement between the results obtained by different analysts in different laboratories using a given measurement procedure.

Felixberger [12] described the results of the initial adhesion tests of seven cementitious CTAs carried out in ten laboratories using two different test slabs. As the first test slab, each of the participating laboratories used a standard test slab that met the EN 1323:2007 requirements [69]. The second concrete slab was purchased by the research organizer and delivered to all of the participating laboratories. The standard deviation of the measurement ranged from 15 to $20 \%$. The tests organized by Felixberger showed the influence of the slab on the value of the determined adhesion. It was also found that more significant differences between individual measurements were present for cementitious CTAs with a lower adhesion value ( $\mathrm{C} 1$ class) than for adhesives with higher adhesion ( $\mathrm{C} 2$ class).

According to Felixberger [12], priming the surface of the concrete slab for testing would unify the surface of the slab in terms of its absorption properties, and would create a situation closer to the actual use, in which the manufacturers of cementitious CTAs recommend the use of a primer before laying ceramic tiles.

In 2007, the Romanian notified laboratory in the scope of EN 12004 initiated interlaboratory measurements of the initial adhesion of CTAs. Nine laboratories, mainly Romanian, participated in the first edition of the study (2008-2009), and five years later they were joined by 27 laboratories of research institutes and manufacturers of CTAs from the following nine countries: Austria, Bulgaria, Croatia, Czech Republic, Germany, Poland, Portugal, Romania and Slovenia [70]. Proficiency tests/interlaboratory comparisons, as mentioned above, were carried out according to uniform rules and under the requirements of EN ISO/IEC 17043 [71]. The initial tensile adhesion strength of four different cementitious CTAs (C2FTE, C2TE, C2TES1 and C2TS1) was tested. All of the laboratories used identical concrete slabs and the same ceramic tiles provided by the test organizer for the tests. According to the authors of the study, more than $90 \%$ of the test results obtained by the participating laboratories can be described as "satisfactory" having $(|z| \leq 2)$, according to EN ISO/IEC 17043; the remaining results were questionable or unsatisfactory [70]. In 2014, the study was extended to the second characteristic, i.e., adhesion strength after immersion in water. In 2018, three characteristics were measured during the tenth jubilee edition of the study: initial adhesion, adhesion after immersion in water, and open time [72]. Sixty-seven laboratories from 25 European countries and Asia participated in the tenth edition of the research. In total, $94 \%$ of the obtained test results were qualified as satisfactory $(|z| \leq 2)$ under EN ISO/IEC 17043. One of the Romanian project's objectives was to show that continuous participation in laboratory proficiency testing programs improves the participants work quality. In this respect, the organizers' research achieved the intended goal.

In meeting the standard requirements of cementitious CTAs, it is worth mentioning the research on the effect of the seasoning water on the adhesion of adhesive mortars [73]. Nosal et al. stored samples of cementitious CTAs in three types of water: in distilled water $(\mathrm{pH}=$ 7.09 , specific conductivity $=0.040 \mathrm{mS} / \mathrm{cm})$, in tap water $(\mathrm{pH}=8.25$, specific conductivity $=$ 
$0.805 \mathrm{mS} / \mathrm{cm})$ and in softened water $(\mathrm{pH}=8.63$, specific conductivity $=1.228 \mathrm{mS} / \mathrm{cm})$. It was found in the study that the origin and type of the water used to condition the samples has a great influence on the adhesion of CTAs. Samples stored in distilled water were characterized by higher adhesion than those stored in tap water or softened water. As emphasized by the authors of the research, in some cases, the difference between the test results was so significant that it determined whether the standard requirements were met. This observation is important in various respects. It seems appropriate to determine, in the future, the type of water used to condition the samples.

The adhesion of the cementitious CTAs is determined in the following system: concrete substrate (slab)-adhesive-ceramic tile. The properties of ceramic tiles approved for use during adhesion tests are specified in the standards referred to for a given test method in EN 12004. However, not all of the parameters that should be characterized by ceramic tiles used for the testing of the adhesion of cementitious CTAs are specified. Niziurska assessed the influence of ceramic tiles' chemical compositions and surface structures on the adhesion of cementitious CTAs [74]. The results obtained in the tests confirmed the impact of the quality of the auxiliary materials (ceramic tiles) used in the tests on their compliance with the standard (threshold value) requirements of the tested CTAs.

\subsection{Manufacturers' Risk Related to the Assessment and Verification of the Constancy of the Performance of the CTAs}

The introduction of any product to the market is associated with risk. The manufacturer's risk is also that his product will be negatively assessed by market surveillance authorities, which will order the manufacturer's product to be tested. In a situation where the product's actual performance is close to the threshold value resulting from the standard's requirements, a situation may arise in which the manufacturer's product is negatively assessed, and his product will have to be removed from the market. This is the case for construction products due to the EU's surveillance and inspection system for construction products [75]. In order to prevent the possibility of such a situation, the manufacturer should carry out an analysis of the measurement uncertainty $[76,77]$. Not taking the risk resulting from the variability of the measurement uncertainty of the test method may create a situation in which the product assessed as compliant by the manufacturer will be assessed as non-compliant in the market surveillance authorities' test. It may also happen that the product found by the manufacturer to be non-compliant meets the threshold value [78].

For this reason, the knowledge of the measurement uncertainty in the testing of a given property is essential for the manufacturer. A risk-aware manufacturer can increase product parameters (colloquially speaking, improve product quality) and minimize the risk. In most cases, however, this means an increase in the production costs of the construction product.

Research carried out in 2016-2020 by the Polish construction supervision authorities of cementitious CTAs showed that many products did not meet the threshold value of adhesion strength [79]. However, it is essential to note that when assessing the compliance of the obtained results with the criteria, the market surveillance authorities applied a simple acceptance rule [80]. The simple acceptance rule means that the product is compliant or noncompliant concerning the result if this result met or did not meet the threshold requirements without considering the variability resulting from the measurement uncertainty.

\subsection{A Few Remarks on the CTAs' Exploitation Conditions}

Many critical comments are made in connection with the adoption in the EN 12004 of adhesion as being crucial for the classification of cementitious adhesives for ceramic tiles. These comments result from the fact that this parameter is determined by measuring the tensile strength (vertical force) and not the parallel shear force [12,81]. Shear stresses in the substrate-CTA—ceramic cladding system may arise due to thermal expansion of the ceramic cladding (for example, on balconies or terraces) or as a result of subsoil contraction (for example, fresh concrete or unsealed cement floor) [82,83]. Unfortunately, shear strength measurements are somewhat complex, unlike the relatively simple tensile adhesion strength 
measurements. For this reason, the shear strength of cementitious CTAs is not ordinarily determined. Fritze and Feichtner described a test method in which the tensile strength of the tile adhesive was determined after a sample was subjected to a controlled shear force [81]. According to the authors, their proposed research method corresponds well to the real-life impacts of cementitious CTA under operating conditions.

It should also be noted that the evaluation and classification of cementitious CTAs are usually carried out relatively shortly after the production of CTAs under laboratory conditions. Many centers dealing with CTAs indicate [84] the need to develop research methods related to the long-term operation of cementitious CTAs.

A constant challenge for the producers of CTAs is the continuous development of ceramic tiles' technology, including large-format ceramic tiles $[85,86]$.

The most crucial challenge facing building material producers is sustainable development, which is a global challenge for construction. The environmental impact of CTAs should be considered in different dimensions. One is to consider CTAs along with ceramic tiles. Shohet and Laufer showed that external ceramic coverings last longer than other covering materials, except for stone [87]. Their environmental performance is influenced by the service life of the building itself and the building materials used. Construction materials' replacement intervals are important in the life cycle assessment of buildings. Ceramic tiles and terracotta tiles have a much longer life than plasterboards, plaster, or renders [88]. CTAs, considered in the aspect of waste materials deriving from demolition, are construction products that can be reused without special treatments. Ceramic tiles can be reused as inert materials for buildings.

Today, CTAs are not assessed in terms of their environmental impact, and voluntary Environmental Product Declarations for CTAs are rare. However, this situation will change. Producers and users must consider the further progress of CTAs through the prism of sustainable development and the sustainable use of materials for their production. Recently, one of the RPP manufacturers introduced vinyl acetate co- and terpolymer produced from renewable, and therefore non-fossil, raw materials [89]. Adding alternative binders to Portland cement can reduce its negative impact on the environment, such as sulfoaluminate cement (CSA), the production of which emits half the amount of carbon dioxide compared to Portland cement [90].

Funding: The author was partially supported by the Smart Growth Operational Programme 2014-2020 (Project number POIR.02.01.00-00-0350/16).

Institutional Review Board Statement: Not applicable.

Informed Consent Statement: Not applicable.

Data Availability Statement: Not applicable.

Acknowledgments: I want to thank Bartosz Michałowski for all his valuable recommendations given in writing this work.

Conflicts of Interest: The author declares no conflict of interest.

\section{References}

1. Carter, C.B.; Norton, M.G. Ceramic Materials: Science and Engineering; Springer: New York, NY, USA, 2007 ; Volume 716, p. 712.

2. Lutz, H.; Bayer, R. Dry Mortars. Ullmann's Encyclopedia of Industrial Chemistry; Willey Online Library: Hoboken, NJ, USA, 2015.

3. Baraldi, L. World production and consumption of ceramic tiles. Ceramic World Rev. 2020, 30, 40-54.

4. Mordor Intelligence, Hyderabad, India. 2020. Available online: https://www.mordorintelligence.com/industry-reports/drymix-mortar-market (accessed on 27 April 2021).

5. Market US, New York, USA. 2020. Available online: https://market.us/report/ceramic-tile-adhesive-market (accessed on 27 April 2021).

6. Verified Market Research, New York, USA. 2019. Available online: https://www.verifiedmarketresearch.com/product/ceramictile-adhesive-market (accessed on 27 April 2021).

7. Harder, J. Market review of the premixed dry mortar industry in Europe. ZKG Int. 2007, 60, 48-61.

8. Winter, C.; Plank, J. The European dry-mix mortar industry (Part 1). ZKG Int. 2007, 60, 62-69. 
9. Michalak, J. Chemia budowlana. Zaprawy budowlane. (Building chemistry. Building mortars). Przemyst Chemiczny 2002, $81,160-164$.

10. Zhi, Z.; Ma, B.; Jian, S.; Su, L.; Guo, Y.; Chen, F. Research on the interface and microstructure of thin layer mortar. ZKG Int. 2016, $69,62-69$.

11. Schulze, J.; Jodlbauer, F.; Adler, K. Polymer Mofyfied Mortars for the Renovation and Rehabilitation of Conrete Structures. In Proceedings of the IXth International Congress on Polymers in Concrete, Bologna, Italy, 15-18 September 1998.

12. Felixberger, J.K. Polymer-modified thin-bed tile adhesive. Institut De Promocio Ceramica: Castelló, Spain, 2008.

13. Nguyen, D.D.; Devlin, L.P.; Koshy, P.; Sorrell, C.C. Impact of water-soluble cellulose ethers on polymer-modified mortars. J. Mater. Sci. 2014, 49, 923-951. [CrossRef]

14. Reports and Data, New York, USA. 2019. Available online: https://www.reportsanddata.com/report-detail/cellulose-ethermarket (accessed on 29 April 2021).

15. Pichniarczyk, P.; Malata, G. Microcalorimetric analysis of methylcellulose influence on the hydration process of tricalcium aluminate, alite and their mixture. J. Therm. Anal. Calorim. 2017, 128, 771-778. [CrossRef]

16. Pichniarczyk, P. The Influence of Methylcellulose on the Hydration Process of C3S, C3A and Mixture of these Phases. Procedia Eng. 2015, 108, 220-230. [CrossRef]

17. Pichniarczyk, P. The influence of methylcellulose on hydration of tricalcium aluminate. Cement Wapno Beton $2013,18,65-73$.

18. Ou, Z.H.; Ma, B.G.; Jian, S.W. Influence of cellulose ethers molecular parameters on hydration kinetics of Portland cement at early ages. Constr. Build. Mater. 2012, 33, 78-83. [CrossRef]

19. Pourchez, J.; Grosseau, P.; Ruot, B. Changes in C3S hydration in the presence of cellulose ethers. Cem. Concr. Res. 2010, 40, 179-188. [CrossRef]

20. Ridi, F.; Fratini, E.; Mannelli, F.; Baglioni, P. Hydration process of cement in the presence of a cellulosic additive. A calorimetric investigation. J. Phys. Chem. B 2005, 109, 14727-14734. [CrossRef]

21. Peschard, A.; Govin, A.; Fredon, E.; Grosseau, P.; Fantozzi, G. Influence of polysaccharides on cement hydration. Key Eng. Mater. 2004, 264, 2141-2144. [CrossRef]

22. Coarna, M.; Georgescu, M.; Puri, A.; Diaconu, D. ESCA, MIP and mechanical characterization of some Portland cement-methylcellulose composites. Key Eng. Mater. 2004, 264, 2153-2156. [CrossRef]

23. Petit, J.Y.; Wirquin, E. Evaluation of various cellulose ethers performance in ceramic tile adhesive mortars. Int. J. Adhes. Adhes. 2013, 40, 202-209. [CrossRef]

24. Bülichen, D.; Kainz, J.; Plank, J. Working mechanism of methyl hydroxyethyl cellulose (MHEC) as water retention agent. Cem. Concr. Res. 2012, 42, 953-959. [CrossRef]

25. Patural, L.; Marchal, P.; Govin, A.; Grosseau, P.; Ruot, B.; Deves, O. Cellulose ethers influence on water retention and consistency in cement-based mortars. Cem. Concr. Res. 2011, 41, 46-55. [CrossRef]

26. Pichniarczyk, P.; Niziurska, M. Properties of ceramic tile adhesives modified by different viscosity hydroxypropyl methylcellulose. Constr. Build. Mater. 2015, 77, 227-232. [CrossRef]

27. Marliere, C.; Mabrouk, E.; Lamblet, M.; Coussot, P. How water retention in porous media with cellulose ethers works. Cem. Concr. Res. 2012, 42, 1501-1512. [CrossRef]

28. Chen, N.; Wang, P.; Zhao, L.; Zhang, G. Water retention mechanism of HPMC in cement mortar. Materials 2020, $13,2918$. [CrossRef] [PubMed]

29. Curto, F.; Monaco, M.; Carrà, S. Rheological properties of cellulose ethers and their application in cementitious tile adhesives formulation. Annu. Trans. Nord. Rheol. Soc. 2019, 27, 53-60.

30. Artioli, G.; Secco, M.; Addis, A. The Vitruvian legacy: Mortars and binders before and after the Roman world. EMU Notes Miner. 2019, 20, 151-202.

31. Sakai, E.; Sugita, J. Composite mechanism of polymer modified cement. Cem. Concr. Res. 1995, 25, 127-135. [CrossRef]

32. Schulze, J. Influence of water-cement ratio and cement content on the properties of polymer-modified mortars. Cem. Concr. Res. 1999, 29, 909-915. [CrossRef]

33. Jenni, A.; Holzer, L.; Zurbriggen, R.; Herwegh, M. Influence of polymers on microstructure and adhesive strength of cementitious tile adhesive mortars. Cem. Concr. Res. 2005, 35, 35-50. [CrossRef]

34. Wang, R.; Wang, P.M. Action of redispersible vinyl acetate and versatate copolymer powder in cement mortar. Constr. Build. Mater. 2011, 25, 4210-4214. [CrossRef]

35. Betioli, A.M.; Gleize, P.J.P.; John, V.M.; Pileggi, R.G. Effect of EVA on the fresh properties of cement paste. Cem. Concr. Compos. 2012, 34, 255-260. [CrossRef]

36. Zhao, G.; Wang, P.; Zhang, G. Principles of polymer film in tile adhesive mortars at early ages. Mater. Res. Express 2018, 6, 025317. [CrossRef]

37. Fujii-Yamagata, A.L.; Cardoso, F.A.; Sarou-Kanian, V.; Daubresse, A.; Prat, E.; Chaouche, M. Skin formation in adhesive mortars evaluated by MRI and interfacial rheology. Cem. Concr. Compos. 2019, 99, 251-261. [CrossRef]

38. Bühler, T.; Zurbriggen, R.; Pieles, U.; Huwiler, L.; Raso, R.A. Dynamics of early skin formation of tiling mortars investigated by microscopy and diffuse reflectance infrared Fourier transformed spectroscopy. Cem. Concr. Compos. 2013, 37, 161-170. [CrossRef]

39. Afridi, M.U.K.; Ohama, Y.; Iqbal, M.Z.; Demura, K. Water retention and adhesion of powdered and aqueous polymer-modified mortars. Cem. Concr. Compos. 1995, 17, 113-118. [CrossRef] 
40. Jenni, A.; Zurbriggen, R.; Holzer, L.; Herwegh, M. Changes in microstructures and physical properties of polymer-modified mortars during wet storage. Cem. Concr. Res. 2006, 36, 79-90. [CrossRef]

41. Petit, J.Y.; Comelli, B.; Perrin, R.; Wirquin, E. Effect of formulation parameters on adhesive properties of ANSI 118-15 and 118-11 compliant tile adhesive mortars. Int. J. Adhes. Adhes. 2016, 66, 73-80. [CrossRef]

42. Brien, J.V.; Mahboub, K.C. Influence of polymer type on adhesion performance of a blended cement mortar. Int. J. Adhes. Adhes. 2013, 43, 7-13. [CrossRef]

43. Kulesza, M.; Debski, D.; Fangrat, J.; Michalak, J. Effect of redispersible polymer powders on selected mechanical properties of thin-bed cementitious mortars. Cement Wapno Beton 2020, 25, 168-177.

44. Barluenga, G.; Hernandez-Olivares, F. SBR latex modified mortar rheology and mechanical behaviour. Cem. Concr. Res. 2004, 34, 527-535. [CrossRef]

45. Schulze, J.; Killermann, O. Long-term performance of redispersible powders in mortars. Cem. Concr. Res. 2001, 31, 357-362. [CrossRef]

46. Pascal, S.; Alliche, A.; Pilvin, P. Mechanical behaviour of polymer modified mortars. Mater. Sci. Eng. A 2004, 380, 1-8. [CrossRef]

47. Medeiros, M.H.F.; Helene, P.; Selmo, S. Influence of EVA and acrylate polymers on some mechanical properties of cementitious repair mortars. Constr. Build. Mater. 2009, 23, 2527-2533. [CrossRef]

48. Mirza, J.; Mirza, M.S.; Lapointe, R. Laboratory and field performance of polymer-modified cement-based repair mortars in cold climates. Constr. Build. Mater. 2002, 16, 365-374. [CrossRef]

49. Patural, L.; Porion, P.; Van Damme, H.; Govin, A.; Grosseau, P.; Ruot, B.; Devès, O. A pulsed field gradient and NMR imaging I; vestigations of the water retention mechanism by cellulose ethers in mortars. Cem. Concr. Res. 2010, 40, 1378-1385. [CrossRef]

50. Kulesza, M.; Dęski, D.; Fangrat, J. Effect of redispersible polymer powder on setting time of thin-bed mortars. MATEC Web Conf. 2018, 163, 04005. [CrossRef]

51. Peng, Y.; Zeng, Q.; Xu, S.; Zhao, G.; Wang, P.; Liu, X. BSE-IA reveals retardation mechanisms of polymer powders on cement hydration. J. Am. Ceram. Soc. 2020, 103, 3373-3389. [CrossRef]

52. Beeldens, A.; Van Gemert, D.; Schorn, H.; Ohama, Y.; Czarnecki, L. From microstructure to macrostructure: An integrated model of structure formation in polymer-modified concrete. Mater. Struct. 2005, 38, 601-607. [CrossRef]

53. Czarnecki, L.; Schorn, H. Nanomonitoring of Polymer Cement Concrete Microstructure/Untersuchung des Mikrogefiiges von Polymer-Zement-Beton im Nanobereich. Restor. Build. Monum. 2007, 13, 141-152. [CrossRef]

54. Dimmig-Osburg, A. Microstructure of PCC-Effects of polymer components and additives. In Proceedings of the 12th International Congress on Polymers in Concrete, Chuncheon, Korea, 27 September 2007; pp. 239-248.

55. Knapen, E.; Van Gemert, D. Cement hydration and microstructure formation in the presence of water-soluble polymers. Cem. Concr. Res. 2009, 39, 6-13. [CrossRef]

56. Tian, Y.; Li, Z.J.; Ma, H.Y.; Jin, N.; Jin, N.G. An investigation on the microstructure formation of polymer modified mortars in the presence of polyacrylate latex. In Proceedings of the International RILEM Conference on Advances in Construction Materials through Science and Engineering, Hong Kong, China, 5-7 September 2011; p. 7177.

57. Silva, D.A.D.; Roman, H.R.; Gleize, P.J.P. Evidences of chemical interaction between EVA and hydrating Portland cement. Cem. Concr. Res. 2002, 32, 1383-1390. [CrossRef]

58. Kotwica, L.; Małolepszy, J. The influence of ethylene-vinyl acetate copolymer redispersible powders on cement hydration. Cement Wapno Beton 2009, 14, 282-291.

59. Kotwica, L.; Małolepszy, J. Polymer-cement and polymer-alite interactions in hardening of cement-polymer composites. Cement Wapno Beton 2012, 17, 12-16.

60. Wang, R.; Li, J.; Zhang, T.; Czarnecki, L. Chemical interaction between polymer and cement in polymer-cement concrete. Bull. Polish Acad. Sci. Tech. Sci. 2016, 785-792. [CrossRef]

61. European Committee for Standardization (CEN). EN 12004:2001 Adhesives for Tiles-Definitions and Specifications; European Committee for Standardization (CEN): Brussels, Belgium, 2001. [CrossRef]

62. European Commission. Summary of References of Harmonized Standards Published in the Official Journal-Regulation (EU) No 305/2011 of the European Parliament and of the Council of 9 March 2011 Laying Down Harmonized Conditions for the Marketing of Construction Products and Repealing Council Directive 89/106/EEC; European Commission: Brussels, Belgium, 2019; Available online: https: / / ec.europa.eu/docsroom/documents/38863 (accessed on 27 April 2021).

63. European Committee for Standardization (CEN). EN 12004:2007+A1:2012 Adhesives for Tiles—Requirements, Evaluation of Conformity, Classification, and Designation; European Committee for Standardization (CEN): Brussels, Belgium, 2012.

64. European Committee for Standardization (CEN). EN 12004-1:2017 Adhesives for Ceramic Tiles_Part 1: Requirements, Assessment, and Verification of Constancy of Performance; Classification, and Marking; European Committee for Standardization (CEN): Brussels, Belgium, 2017.

65. Regulation (EU) No. 305/2011 of the European Parliament and of the Council. Available online: https:/ / eur-lex.europa.eu/legalcontent/EN/TXT/?uri=CELEX:32011R0305 (accessed on 4 May 2021).

66. The Council of European Communities. Council Directive of 21 December 1988 on the approximation of laws, regulations and administrative provisions of the Member States relating to construction products. Off. J. Eur. Communities 1989, 40, 12-26. 
67. Kulesza, M.; Michalak, J. Zmiany w ocenie i weryfikacji stałości właściwości użytkowych cementowych zapraw klejących do płytek ceramicznych w ostatnim trzydziestoleciu (Changes in assessment and verification of constancy of performance of cementitious ceramic tiles adhesives over the last thirty years). Mater. Bud. 2020, 5, 2-6.

68. International Organization for Standardization (ISO). ISO 13007-1:2014 Ceramic Tile—Grouts and adhesive—Part 1:Terms, Definitions and Specifications for Adhesive; International Organization for Standardization ISO: Geneva, Switzerland, 2014.

69. European Committee for Standardization (CEN). EN 1323:2007 Adhesives for Tiles_Concrete Slabs for Tests; European Committee for Standardization (CEN): Brussels, Belgium, 2007.

70. Coarna, M.; Guslicov, G.; Stancu, C.; Vlad, C. Interlaboratory test on adhesives for ceramic tiles in the last 5 years. In Proceedings of the 4th International Proficiency Testing Conference, Brasov, Romania, 18-20 September 2013; pp. 17-20.

71. European Committee for Standardization (CEN). EN ISO/IEC 17043:2010 Conformity Assessment-General Requirements for Proficiency Testing; European Committee for Standardization (CEN): Brussels, Belgium, 2010.

72. Stancu, C. The 10th edition of interlaboratory tests adhesives for ceramic tiles-an anniversary edition. In Proceedings of the 7th International Proficiency Testing Conference, Oradea, Romania, 10-13 September 2019; p. 99.

73. Nosal, K.; Niziurska, M.; Wieczorek, M. Wpływ zanieczyszczeń zawartych w wodzie przeznaczonej do sezonowania zapraw klejowych do płytek na ich przyczepność. Prace Instytutu Ceramiki i Materiałów Budowlanych 2015, 8, 61-70.

74. Niziurska, M. Znaczenie właściwości płytek ceramicznych w zapewnieniu trwałości okładzin mocowanych zaprawami cementowymi. Prace Instytutu Ceramiki i Materiałów Budowlanych 2013, 6, 17-26.

75. Regulation (EU) No. 765/2008 of the European Parliament and of the Council. Available online: https://eur-lex.europa.eu/legalcontent/EN/TXT/HTML/?uri=CELEX:32008R0765\&from (accessed on 7 May 2021).

76. Hinrichs, W. The impact of measurement uncertainty on the producer's and user's risks, on classification and conformity assessment: An example based on tests on some construction products. Accredit. Qual. Assur. 2010, 15, 289-296. [CrossRef]

77. Rossi, G.B.; Crenna, F. A probabilistic approach to measurement-based decisions. Measurement 2006, 39, 101-119. [CrossRef]

78. Szewczak, E.; Piekarczuk, A. Performance evaluation of the construction products as a research challenge. Small error-big difference in assessment? Bull. Pol. Acad. Sci. Tech. Sci. 2016, 675-686. [CrossRef]

79. Łukasik, M.; Michałowski, B.; Michalak, J. Assessment of the Constancy of Performance of Cementitious Adhesives for Ceramic Tiles: Analysis of the Test Results Commissioned by Polish Market Surveillance Authorities. Appl. Sci. 2020, 10, 6561. [CrossRef]

80. Kulesza, M.; Łukasik, M.; Michalowski, B.; Michalak, J. Risk related to the assessment and verification of the constancy of performance of construction products. Analysis of the results of the tests of cementitious adhesives for ceramic tiles commissioned by Polish construction supervision authorities in 2016-2020. Cement Wapno Beton 2020, 25, 444-456.

81. Fritze, P.; Feichtner, G. Flexibility of CTA Beyond Standards. Qualicer 2018, 1-13.

82. Wetzel, A.; Zurbriggen, R.; Herwegh, M.; Greminger, A.; Kaufmann, J. Long-term study on failure mechanisms of exterior applied tilings. Constr. Build. Mater. 2012, 37, 335-348. [CrossRef]

83. Maranhão, F.L.; John, V.M. Bond strength and transversal deformation aging on cement-polymer adhesive mortar. Constr. Build. Mater. 2009, 23, 1022-1027. [CrossRef]

84. De Freitas, V.P.; Sá, A.V. Cementitious adhesives performance during service life. In Proceedings of the 10DBMC International Conference On Durability of Building Materials and Components, Lyon, France, 17-20 April 2005.

85. Zurbriggen, R.; Herwegh, M. Daily and seasonal thermal stresses in tilings: A field survey combined with numeric modeling. Mater. Struct. 2016, 49, 1917-1933. [CrossRef]

86. Wetzel, A.; Herwegh, M.; Zurbriggen, R.; Winnefeld, F. Influence of shrinkage and water transport mechanisms on microstructure and crack formation of tile adhesive mortars. Cem. Concr. Res. 2012, 42, 39-50. [CrossRef]

87. Shohet, I.M.; Laufer, A. Exterior cladding methods: A technoeconomic analysis. J. Constr. Eng. Manag. 1996, 122, 242-247. [CrossRef]

88. Janjua, S.Y.; Sarker, P.K.; Biswas, W.K. Impact of service life on the environmental performance of buildings. Buildings $2019,9,9$. [CrossRef]

89. Wacker Chemie AG. Vinneco; Wacker Chemie AG: Munich, Germany, 2021; Available online: https:/ /www.wacker.com/cms/enus/products/brands/vinneco/vinneco.html (accessed on 11 June 2021).

90. Trigo, T.; Flores-Colen, I.; Silva, L.; Vieira, N.; Raimundo, A.; Borsoi, G. Performance and Durability of Rendering and Basecoat Mortars for ETICS with CSA and Portland Cement. Infrastructures 2021, 6, 60. [CrossRef] 